\title{
PENGARUH PENERAPAN BOOKLET MENU SEIMBANG TERHADAP PENINGKATAN BERAT BADAN BAYI USIA 6-12 BULAN
}

\author{
Rosalinna $^{1}$, Apri Sulsitianingsih ${ }^{2}$ \\ ${ }^{1}$ Poltekkes Kemenkes Surakarta Jurusan Kebidanan \\ ${ }^{2}$ STIKes Muhammadiyah Pringsewu, Prodi Kebidanan \\ Diterima : 7 Januari 2019, Disetujui : 4 Februari 2019
}

\begin{abstract}
Background: In infancy, breast milk is the best food. Since the age of 6 months, babies begin to be given complementary breast milk food (MP-ASI). Giving the wrong MP-ASI will have an impact on nutritional disorders. The Karanganyar Regency in 2016 was $413(0.8 \%)$, while the cases of under-fives were malnutrition which were found in 22 children. The aim of this study was to determine the effect of applying a balanced menu booklet to increasing infant weight at the age of 6-12 months in Karanganyar Regency. The method used in this study is the method in this study. Method: This research uses a quantitative method with a Quasy experiment in the form of pre-post test design. The sample in this study was 6-12 months Mother and Baby in Karanganyar District who had fulfilled the Inclusion and Exclusion criteria as many as 20 samples per group. Data analysis using paired and $T$ independent $T$ test. Results: The results of the control group study showed an average baby weight of 6.74 (0.63) $\mathrm{kg}$ to $6.86(0.62) \mathrm{kg}$. Similarly, in the intervention group the average baby weight from $6.88(0.44) \mathrm{kg}$ to 7.25 (0.43) $\mathrm{kg}$. The group given the booklet had a difference in the average increase in body weight higher $(0.390(0.151) \mathrm{kg})$ when compared to the group given only lectures $(0.125$ (0.121) kg). Conclusion: The statistical test results $\rho$ value $<0.001$ which means there is an effect of the Implementation of a Balanced Menu Booklet Against the Increased Body Weight of 6-12 Months Babies in Karanganyar Regency. Health workers are advised to improve counseling skills to improve infant feeding practices that result in increased infant growth
\end{abstract}

Keywords :booklets, balanced menu, 6-12 months babies

\section{PENDAHULUAN}

Pada tahap awal kehidupan, menyusui merupakan faktor penting yang berkontribusi pada kesehatan anak dan kesejahteraan. Setelah 6 bulan, Bayi membutuhkan Makanan Pendamping Air Susu Ibu (MP-ASI) dilengkapi dengan berbagai makanan lain, dan istilah "menyapih" digunakan untuk menggambarkan tahap ini dalam kehidupan seorang anak. Pengenalan ini makanan pendamping merupakan tahap penting berikutnya berlangsung gizi anak, dan menjadi periode kritis karena kemungkinan besar terpapar patogen (Sheth and Dwivedi, 2006)

Masalah gizi terutama gizi kurang merupakan masalah yang sering terjadi pada bayi. Asupan makan yang tidak seimbang yaitu asupan makan yang defisit menyebabkan balita mengalami periode kritis seperti gizi kurang. Kekurangan gizi pada balita bahkan terjadinya gizi buruk dapat menyebabkan kematian. (Pratiwi and Puspitasari, 2017) keadaan kurang gizi pada anak karena kebiasaan 
pemberian MP-ASI yang tidak tepat. Ketidaktahuan tentang cara pemberian makanan pada anak serta adanya kebiasaan yang merugikan kesehatan, secara langsung dan tidak langsung menjadi penyebab utama terjadinya masalah kurang gizi pada anak, khususnya pada anak usia di bawah 2 tahun.(Marfuah and Kurniawati, 2017)

Hasil utama Riset Kesehatan Dasar menunjukkan tahun 2013 di Indonesia. kasus gizi kurang dan buruk sebanyak $19,6 \%$, sedangkan tahun 2018 kasus gizi kurang masih $17,7 \%$. Hal ini menjelaskan bahwa masalah gizi kurang belum tertangani di Indonesia. Di Provinsi Jawa tengah sendiri kasus gizi kurang masih menjadi masalah. Pada laporan Riskesdas menunjukkan tidak ada perbedaan yang signifikan. Pada tahun 2013 kasus gizi kurang dan buruk sekitar 18\%, sedangkan pada tahun 2018 kasus gizi kurang dan buruk masih $17 \%$. Oleh sebab itu diperlukan penatalaksanaan yang tepat untuk mengatasi permasalahan gizi tersebut.(Kemenkes RI., 2018)

Laporan profil kesehatan kabupaten Karanganyar tahun 2016 sebanyak 63.731, yang ditimbang sebanyak 49,911 (78,3\%). Dari balita yang ditimbang pada tahun 2016 status balita garis merah sebanyak $413(0,8 \%)$, sedang kasus balita gizi buruk yang ditemukan sebanyak 22 balita, semua balita gizi buruk yang diketemukan, semuanya mendapatkan perawatan (100\%).(Karanganyar, 2017)

Nutrisi seimbang yang diperlukan untuk mendukung pertumbuhan yang optimal, untuk menghindari penyakit defisiensi, untuk mencegah keracunan, dan juga untuk mencegah timbulnya penyakit yang mungkin mengganggu anak bertahan hidup. (Siagian and
Halisitijayani, 2015) Pengetahuan ibu dalam pengaturan konsumsi makan dengan pola makan seimbang sangat diperlukan untuk menjadikan balita memiliki status gizi baik. Perilaku yang positif dapat dibentuk dari pengetahuan yang baik, sehingga cara yang tepat untuk meningkatkan pengetahuan adalah dengan menggunakan media sebagai pendidikan kesehatan. Pengetahuan gizi ibu meliputi mampu membuat makanan yang memiliki komposisi beraneka ragam atau bervariasi untuk dikonsumsi balita sehingga kebutuhan zat gizi balita dapat tercukupi. (Ma'munah, 2015)

Upaya peningkatan status kesehatan dan gizi pada anak melalui perbaikan pengetahuan dan perilaku masyarakat dalam pemberian MP-ASI. MP-ASI merupakan bagian yang tidak dapat dipisahkan dari upaya perbaikan gizi secara menyeluruh. Upaya perbaikan pengetahuan ini dapat dilakukan melalui pendidikan kesehatan. (Marfuah and Kurniawati, 2017) Pengetahuan ibu dapat ditingkatkan dengan pemberian pendidikan kesehatan, salah satunya dengan media booklet. Media Booklet dipilih sebagai media penyuluhan karena mampu menyebarkan informasi dalam waktu relatif singkat. Bentuk fisiknya menyerupai buku yang tipis dan lengkap informasinya, yang memudahkan media tersebut untuk dibawa.(Marfuah and Kurniawati, 2017)

Pada penelitian Pertiwi dan Puspitasari (2017) peningkatan pengetahuan pada ibu setelah diberikan pendidikan kesehatan dengan media booklet, sehingga informasi pada booklet sangat efektif untuk peningkatan pengetahuan pada ibu. Booklet akan memberikan kesan kepada pembaca jika 
disajikan dengan gambar yang menarik sehingga booklet tidak formal dan kaku.

Penelitian ini bertujuan untuk mengetahui pengaruh penerapan booklet menu seimbang terhadap peningkatan berat badan bayi usia 6-12 bulan di Kabupaten Karanganyar.

\section{METODE PENELITIAN}

Penelitian ini menggunakan desain quasy eksperiment dengan pendekatan pretest-postest control group desain. Pendekatan pretest-postest control group desain, pada desain ini kelompok eksperimen dan kontrol dilakukan pengukuran sebelum (pre-test) dan sesudah (post-test) pemberian treatment pada dua kelompok. Pre-test dan post-test dilakukan dengan menggunakan instrument booklet dan timbangan bayi.

Populasi dalam penelitian ini Ibu dan Bayi 6-12 bulan pada bulan September di Kabupaten Karanganyar. Peneliti menetapkan sampel dalam penelitian ini sejumlah 40 responden. 20orang untuk kelompok intervensi dan 20 orang untuk kelompok kontrol. Penelitian ini menggunakan teknik purposive sampling. Krliteria inklusi pada penelitian ini adalah Ibu yang memiliki bayi 6-12 bulan di wilayah kerja Kabupaten Karanganyar dan Ibu bersedia menjadi responden. Kriteria eksklusi pada penelitian ini Bayi yang memiliki kelainan kongenital dan komplikasi.

Proses penelitian pada kelompok intervensi dilakukan sebagai berikut: Memberikan materi booklet menu seimbang setiap minggu dengan durasi 1 jam setiap sesi selama 2 minggu, Penelitian berlangsung 2 kali edukasi. Pada kelompok kontrol:
Memberikan materi ceramah tentang menu seimbang setiap minggu dengan durasi 1 jam setiap sesi selama 2 minggu.

Penelitian berlangsung 2 kali edukasi. Analisis data menggunakan univariat dalam bentuk tendency central dan bivariat menggunakan $T$ Paired test dan $T$ independent

\section{HASIL PENELITIAN}

Penelitian ini untuk melihat pengaruh Penerapan Booklet Menu Seimbang Terhadap Peningkatan Berat Badan Bayi Usia 6-12 Bulan Di Kabupaten Karanganyar. Tahap - tahap yang dilakukan adalah sebagai berikut

Tabel 1. Pengaruh Penerapan Booklet Menu Seimbang Terhadap Peningkatan Berat Badan Bayi Sebelum Dan Setelah Penelitian Pada Kelompok Intervensi

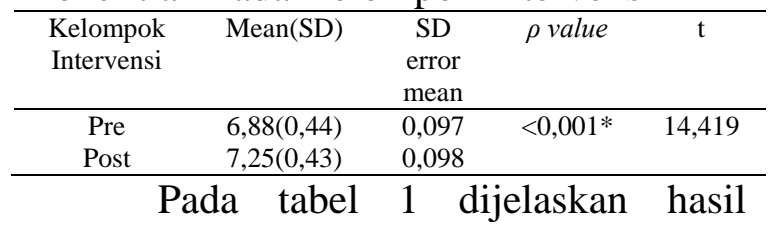
penelitian pre test dan post test pada kelompok intervensi. Pada data pre test didapatkan rata-rata berat badan bayi $6,88(0,44) \quad \mathrm{kg}$. Setelah dilakukan intervensi didapatkan nilai post test menjadi $7,25(0,43) \mathrm{kg}$. Hasil uji statistik menunjukkan nilai $\rho$ value $<0,001$ dengan nilai $\mathrm{t}=14,419$, yang berarti bahwa ada perbedaan yang signifikan antara sebelum dan setelah penelitian pada kelompok intervensi

Tabel 2. Pengaruh Pendidikan Menu Seimbang Terhadap Peningkatan Berat Badan Bayi Sebelum Dan Setelah Penelitian Pada Kelompok Kontrol

\begin{tabular}{ccccc}
\hline $\begin{array}{c}\text { Kelompok } \\
\text { Intervensi }\end{array}$ & Mean(SD) & $\begin{array}{c}\text { SD error } \\
\text { mean }\end{array}$ & $\rho$ value & $\mathrm{t}$ \\
\hline Pre & $6,74(0,63)$ & 0,14 & 0,002 & 3,684 \\
Post & $6,86(0,62)$ & 0,14 & & \\
\hline
\end{tabular}


Pada tabel 2 dijelaskan hasil penelitian pre test dan post test pada kelompok kontrol. Pada data pre test didapatkan rata-rata berat badan bayi $6,74(0,63) \quad \mathrm{kg}$. Setelah dilakukan intervensi didapatkan nilai post testmenjadi 6,86(0,62) kg. Hasil uji statistik menunjukkan nilai $\rho$ value $=$ 0,002 dengan nilai $\mathrm{t}=3,684$, yang berarti bahwa ada perbedaan yang signifikan antara sebelum dan setelah penelitian pada kelompok control

Tabel 3. Pengaruh Penerapan Booklet Menu Seimbang Terhadap Peningkatan Berat Badan Bayi Usia 6-12 Bulan Di Kabupaten Karanganyar

\begin{tabular}{cccccc}
\hline Kelompok & Mean(SD) & $\begin{array}{c}\text { Mean } \\
\text { Dif }\end{array}$ & $\begin{array}{c}95 \% \\
\text { CI }\end{array}$ & $\begin{array}{c}\rho \\
\text { value }\end{array}$ & $t$ \\
\hline Kontrol & $0,125(0,121)$ & 0,266 & $0,177-$ & $<0,001$ & 6,107 \\
& & & 0,352 & & \\
Perlakuan & $0,390(0,151)$ & & & & \\
\hline
\end{tabular}

selisih peningkatan berat badan pada kelompok kontrol dan kelompok perlakuan. Pada kelompok kontrol didapatkan didapatkan rata-rata peningkatan berat badan bayi 0,125 $(0,121) \mathrm{kg}$. Pada kelompok intervensi didapatkan rata-rata peningkatan berat badan bayi $0,390(0,151) \mathrm{Kg}$. Hasil uji statistik menunjukkan nilai $\rho$ value $<$ 0,001 dengan nilai $t=6,107$, yang berarti bahwa ada perbedaan yang signifikan pada kelompok kontrol dan intervensi. Sehingga dapat disimpulkan ada pengaruh Penerapan Booklet Menu Seimbang Terhadap Peningkatan Berat Badan Bayi Usia 6-12 Bulan Di Kabupaten Karanganyar.

\section{PEMBAHASAN}

Status gizi rendah, terutama di kalangan anak-anak, akan menghambat perkembangan Indonesia dalam jangka menengah dan panjang, merusak daya saing ekonomi dan kualitas. Dari sumber daya manusianya, dengan risiko bahwa negara tersebut akan terjebak dalam perangkap pendapatan menengah. Faktanya anak-anak dengan status gizi rendah -terutama mereka yang terhambat pertumbuhannya, tidak mencapai pertumbuhan optimal dalam kemampuan intelektual atau kemampuan fisikal dan kurang produktif ketika mereka bergabung dengan tenaga kerja saat dewasa.(Isdijoso et al., 2015)

Usia 6-24 bulan merupakan usia yang sangat rawan karena pada usia ini merupakan masa peralihan dari ASI ke pengganti ASI atau ke makanan sapihan. Jika anak usia 6-24 bulan tidak cukup gizi dari MP-ASI, maka akan mengakibatkan gangguan pertumbuhan dan kurang gizi, oleh sebab itu dalam mengatasi masalah kurang gizi maka diperlukan perbaikan kuantitas dan kualitas MP-ASI. Untuk memperoleh MPASI yang baik secara kuantitas dan kualitas maka diperlukan peranan petugas kesehatan untuk memberikan informasi tentang praktek pemberian makanan yang baik dan tepat untuk anak di bawah usia 2 tahun kepada ibu, pengasuh, dan keluarga.(Marfuah and Kurniawati, 2017)

Penelitian dipelbagai negara maju menunjukkan bahwa MPASI buatan rumah kaya zat besi memiliki akseptabilitas yang rendah pada usia 6-8 bulan. Hal ini kemungkinan disebabkan keterampilan oromotor yang baru dilatih belum mampu mengonsumsi tekstur yang kasar. Oleh sebab itu, pada tahap awal para ahli nutrisi memikirkan untuk melakukan fortifikasi zat besi dan zat-zat lain yang harus ditambahkan pada MPASI (Damayanti Rusli Sjarif et al., 2015)

Pengetahuan ibu tentang gizi seimbang, jenis dan sumber nutrisi akan 
berdampak pada status gizi bayi. Pengetahuan ibu pada gizi seimbang merupakan aspek dalam pemilihan dan penyediaan bahan makanan untuk keluarga. Pengetahuan gizi orang tua tentang bahan makanan akan mempengaruhi hidangan yang ada bertugas di keluarga. (Siagian and Halisitijayani, 2015)

Pada kelompok kontrol didapatkan peningkatan rata-rata berat badan bayi $6,74(0,63) \mathrm{kg}$ menjadi $6,86(0,62) \mathrm{kg}$. Hasil uji statistik tetap menunjukkan ada perbedaan yang signifikan antara sebelum dan setelah penelitian pada kelompok Kontrol.Hasil ini menjelaskan metode ceramahpun memiliki perbedaan yang signifikan. Hal ini dapat disebabkan karena pada bayi 6-12 bulan akan mengalami pertumbuhan atau penambahan berat badan setiap bulannya. Oleh sebab itu peningkatan berat badan pada kelompok kontrol ini dapat disebabkan karena factor internal pertumbuhan pada bayi 6-12 bulan.

Pendidikan gizi didefinisikan sebagai instruksi atau pelatihan dimaksudkan untuk menghasilkan pengetahuan terkait gizi dan / atau keterampilan yang berhubungan dengan gizi dan disediakan di individu.Pendidikan gizi juga berdampak pada ketahanan pangan, gizi masyarakat dan kesehatan intervensi.Ini juga terbukti mampu meningkatkan perilaku diet dan status gizi pada sendiri. Selain itu memiliki efek jangka panjang pada perilaku pemberian makan orang tua berdampak pada kesehatan anak-anak mereka.(Meena and Meena, 2018)

Menyusun menu seimbang dengan cara pada setiap menu hidangan harus mengandung kalori dari karbohidrat, protein, lemak, di sempurnakan dengan vitamin dan mineral. Penyusunan menu balita yang baik dengan cara: memilih makanan yang cukup mengandung kalsium dan zat besi Menu makanan balita ditentukan sesuai dengan pertumbuhan anak, kemampuan menerima rangsangan makan dan mencerna makanan. (Nugraheni, 2015)

Sama halnya pada kelompok intervensi rata-rata berat badan bayi dari $6,88(0,44) \mathrm{kg}$ menjadi $7,25(0,43) \mathrm{kg}$, hasil uji statistik ada perbedaan yang signifikan antara sebelum dan setelah penelitian pada kelompok intervensi. Bila dibandingkan dengan kelompok control nilai $\mathrm{t}=3,684$, kelompok intervensi yang diberi booklet menunjukkan nilai yang lebih besar yaitu $\mathrm{t}=14,419$, sehingga dampak yang ditimbulkan pada kelompok intervensi yang diberikan booklet

Kelebihan booklet seperti dapat disimpan dalam waktu yang relatif lama, dapat dipelajari secara mandiri, dapat membantu media lain, selain itu booklet juga memiliki kelemahan yaitu pembaca dituntut untuk memiliki kemampuan membaca (Suiraoka, 2012). Oleh karena itu, pengetahuan ibu menggunakan booklet lebih tinggi daripada metode ceramah.

Pada dasarnya kelompok yang diberikan booklet memiliki selisih peningkatan rata-rata berat badan lebih tinggi $(0,390(0,151) \quad \mathrm{Kg}) \quad$ bila dibandingkan dengan kelompok yang hanya diberikan ceramah saja $(0,125(0,121) \quad \mathrm{kg})$.Hasil uji statistik disimpulkan ada pengaruh Penerapan Booklet Menu Seimbang Terhadap Peningkatan Berat Badan Bayi Usia 6-12 Bulan Di Kabupaten Karanganyar.Hal ini dikarenakan pemberian booklet dapat memiliki beberapa keuntungan bila dibandingkan dengan hanya ceramah 
saja.Media Booklet dipilih sebagai media penyuluhan karena mampu menyebarkan informasi dalam waktu relatif singkat. Bentuk fisiknya menyerupai buku yang tipis dan lengkap informasinya, yang memudahkan media tersebut untuk dibawa.(Marfuah and Kurniawati, 2017).

Booklet mudah dibawa-bawa dan dapat meningkatkan pengetahuan ibu. Dengan memadainya pengetahuan ibu akan memberikan makanan enak untuk keluarga, terutama anak-anak di bawah lima. Jadi diharapkan nutrisi untuk anakanak akan dipenuhi menurut mereka kebutuhan. Kurangnya pengetahuan tentang gizi akan mempengaruhi malnutrisi; mempengaruhi munculnya masalah gizi akan mengganggu pertumbuhan dan perkembangan anakanak. Penelitian menunjukkan bahwa ada hubungan antara pengetahuan ibu tentang nutrisi seimbang dengan nutrisi status anak-anak (Siagian and Halisitijayani, 2015)

Hasil penelitian sejalan dengan penelitian Hestuningtyas tahun 2014 menunjukkan hasil bahwa pada kelompok perlakuan, pemberian konseling gizi dapat meningkatkan pengetahuan, sikap, dan praktik ibu dalam pemberian makan anak, serta asupan zat gizi anak secara signifikan $(\mathrm{p}=0,022)$ pada awal dan akhir penelitian. Hasil tersebut menguatkan penelitian yang menyebutkan bahwa edukasi gizi dengan cara konseling gizi sangat berperan penting dalam memperbaiki kepatuhan diet karena konseling gizi adalah suatu pendekatan personal yang digunakan untuk menolong individu memperoleh pengertian yang lebih baik mengenai permasalahan gizi yang dihadapi dan memotivasi menuju perubahan perilaku. Selanjutnya individu mampu mengambil langkah- langkah dalam mengatasi permasalahan gizi tersebut, termasuk perubahan praktik pemberian makan.(Hestuningtyas and Noer, 2014)

Meningkatnya perilaku ibu mengenai pemberian makan pada anak, menjadikan asupan zat gizi anak juga meningkat. Hal tersebut menunjukkan bahwa konseling gizi yang dilakukan 1 kali tiap minggu terbukti cukup efektif dalam perubahan perilaku pemberian makan.(Marfuah and Kurniawati, 2017) hal ini sesuai dengan penelitian yang dilakukan (Nugraheni, 2015) yang menjelaskan bahwa terdapat hubungan pengetahuan ibu tentang penyusunan menu dengan status gizi balita.Menu yang seimbang yang diberikan orang tua dapat meningkatkan status gizi balita. Pemberian edukasi yang tepat dapat memaksimalkan pengetahuan ibu sehingga peningkatan berat badan bayi dapat optimal.

Berdasarkan hasil temuan penelitian, kajian teori dan elaborasi penelitian. Maka peneliti menarik kesimpulan bahwa terdapat pengaruh yang signifikan penerapan booklet menu seimbang terhadap peningkatan berat badan bayi 6-12 bulan di Kabupaten Karanganyar

\section{KESIMPULAN DAN SARAN}

Kesimpulan pada penelitian ini adalah:

1. Ada perbedaan yang signifikan antara sebelum dan setelah penelitian pada kelompok intervensi

2. Ada perbedaan yang signifikan antara sebelum dan setelah penelitian pada kelompok kontrol

3. Ada pengaruh Penerapan Booklet Menu Seimbang Terhadap Peningkatan Berat Badan Bayi Usia 
6-12 Bulan Di Kabupaten

Karanganyar

Tenaga kesehatan disarankan untuk meningkatkan kemampuan konseling untuk meningkatkan praktik pemberian makan bayi yang menghasilkan peningkatan pertumbuhan bayi dimungkinkan, terlepas dari kondisi ekonomi dan juga hemat biaya.Meskipun keluarga sederhana, keluarga harus didorong untuk memleri makan makanan yang kaya energi dan protein yang higienis dan murah dengan satu buah setiap hari karena praktik yang mahal tidak mungkin mencapai kepatuhan berkelanjutan. Mengajar keluarga untuk meningkatkan frekuensi makan, meningkatkan keragaman makanan, memodifikasi makanan rumah tangga serta meningkatkan kesadaran tentang menuseimbang, dapat mengurangi insiden malnutrisi selanjutnya.

\section{DAFTAR RUJUKAN}

Damayanti Rusli Sjarif Et Al. (2015) Rekomendasi Praktik Pemberian Makan Berbasis Bukti Pada Bayi Dan Batita Di Indonesia Untuk Mencegah Malnutrisi Unit. Jakarta: Idai.

Hestuningtyas, T. R. And Noer, E. R. (2014) 'Pengaruh Konseling Gizi Terhadap Pengetahuan, Sikap, Praktik Ibu Dalam Pemberian Makan Anak, Dan Asupan Zat Gizi Anak Stunting Usia 1-2 Tahun Di Kecamatan Semarang Timur', Journal of Nutrition College, 3(1), Pp. 17-25.

Isdijoso, W. Et Al. (2015) 'Food And Nutrition Security In Indonesia : A Strategic Review Improving Food And Nutrition Food And Nutrition Security In Indonesia : A Strategic
Review', The Smeru Research Institute.

Karanganyar, Di. (2017) Profil Kesehatan Kabupaten Karanganyar Tahun 2016. Karanganyar.

Kemenkes Ri. (2018) Riset Kesehatan Dasar. Jakarta.

Ma'munah (2015) 'Pengaruh Pendidikan Kesehatan Dengan Booklet Terhadap Pengetahuan Nutrisi Ibu Laktasi Di Wilayah Kerja Puskesmas Ciputat Timur'.

Marfuah, D. And Kurniawati, I. (2017) 'Upaya Peningkatan Pengetahuan Ibu Tentang Mp Asi Dengan Edukasi Gizi Melalui Booklet', In The 6th University Research Colloquium 2017, Pp. 273-280.

Meena, S. And Meena, P. (2018) 'Effect Of Nutrition Education Intervention On Undernutrition Among Under Five Children In Urban And Rural Areas Of Bhopal District , Madhya Pradesh', International Journal of Community Medicine And Public Health, 5(10), Pp. 4536-4542.

Nugraheni, E. P. (2015) Hubungan Pengetahuan Ibu Tentang Penyusunan Menu Balita Dengan Status Gizi Balita Di Desa Kemiri, Kecamatan Kaloran , Kabupaten Temanggung. Universitas Negeri Yogyakarta.

Pratiwi, Y. F. And Puspitasari, D. I. (2017) 'Efektivitas Penggunaan Media Booklet Terhadap Pengetahuan Gizi Seimbang Pada Ibu Balita Gizi Kurang Di Kelurahan Semanggi Kecamatan Pasar Kliwon Kota Surakarta', Jurnal Kesehatan, 10(1), Pp. 5868.

Sheth, M. And Dwivedi, R. (2006) 
'Complementary Foods Associated Diarrhea', Indian Journal of Pediatrics, 73(4).

Siagian, C. M. And Halisitijayani, M. (2015) 'Original Research Article Mothers Knowledge On Balanced Nutrition To Nutritional Status Of
Children In Puskesmas ( Public Health Center ) In The District Of Pancoran, Southern Jakarta 2014', International Journal of Current Microbiology And Applied Sciences, 4(7), Pp. 815-826. 